\title{
Investigating the role of resilience in psychological vulnerability of Birjand Islamic Azad University employees in the pandemic COVID-19
}

\author{
Samaneh Sadat Jafartabatabaei ${ }^{1}$, Toktam Sadat Jafartabatabaei ${ }^{2}$, Seyyed Vahid Javadi ${ }^{3}$ \\ 1-Assistant Professor, Department of Educational Psychology, Birjand Branch, Islamic Azad University, Birjand, \\ Iran. \\ 2-Assistant Professor, Department of Educational Psychology, Birjand Branch, Islamic Azad University, Birjand, \\ Iran(Corresponding Author). E-mail: Toktamtabatabaee@yahoo.com \\ 3-PhD Candidate in Educational Psychology, Department of Educational Psychology, Birjand Branch, Islamic Azad \\ University, Birjand, Iran.
}

Received: $20 / 10 / 2020$

Accepted: 11/01/2021

\begin{abstract}
Introduction: The emergence of COVID-19 and its consequences has led to fear, worry and anxiety among people around the world.

Aim: The goal of this study was to investigate the role of resilience in predicting the psychological vulnerability of employees of the Birjand Islamic Azad University.

Method: This study was descriptive and the community was the staff of Birjand Azad University in 2020. 123 person were randomly selected based on Morgan's table and the questionnaires included Connor and Davidson resilience and psychiatric symptoms. For data analysis, in addition to the mean and standard deviation, Pearson correlation test and multiple regression analysis were used and data analysis was performed using SPSS 21 statistical software.

Results: The findings showed a significant relationship between the total resilience score and psychological vulnerability. Among the subscales, depression, hypersensitivity, obsessivecompulsive disorder, anxiety, and aggression were the most correlated with resilience, respectively $(\mathrm{P}<0.001)$. Also, the results of linear regression analysis showed that resilience was able to predict a total of $40 \%$ of psychological vulnerability and its subscales $(\mathrm{P}<0.001)$.

Conclusion: Therefore, it can be concluded that increasing resilience can lead to a decrease in the subscales of psychological vulnerability of individuals. The results of this study can also be used to diagnose the psychological damage caused by the COVID-19 pandemic crisis in the staff of Birjand Azad University and to plan the necessary psychological interventions in this target group.
\end{abstract}

Keywords: Covid-19, Psychological vulnerability, Resilience

How to cite this article : Jafartabatabaei SS, Jafartabatabaei TS, Javadi SV. Investigating the role of resilience in psychological vulnerability of Birjand Islamic Azad University employees in the pandemic COVID-19. Shenakht Journal of Psychology and Psychiatry. 2021; 7 (6): 115-125 . URL: http://shenakht.muk.ac.ir/article-1-980-en.pdf

Copyright ( 2018 the Author (s). Published by Kurdistan University of Medical Sciences. This is an open access article distributed under the terms of the Creative Commons Attribution-Non Commercial License 4.0 (CCBY-NC), where it is permissible to download, share, remix, transform, and buildup the work provided it is properly cited. The work cannot be used commercially without permission from the journal. 


\title{
بررسى نقش تاب آورى در آسيبذيذيرى روانى كار كنان دانشكاه آزاد اسلامى بير جند در بحران ياندمى كوويد-19
}

\begin{abstract}
سمانه سادات جعفر طباطبايى'، تكتم سادات جعفرطباطبايى '، سيد وحيد جوادى"

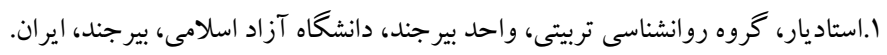

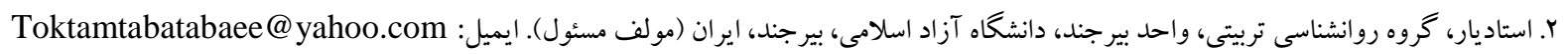

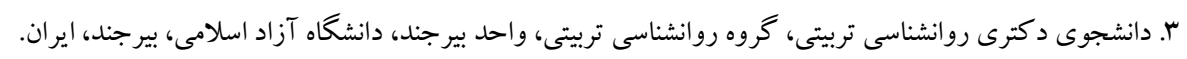

مقدمه: ظهور كوويد 19 و ييامدهاى آن منجر به ترس، نخرانى و اضطراب در بين افراد در سراسر جهان شده است. هدف: هدف از اين يثوهش بررسى نقش تابآورى در بيشبينى آسيب بذيرى روانى است.

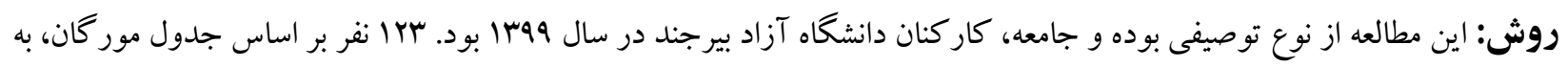

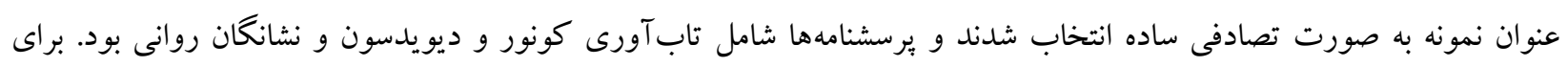

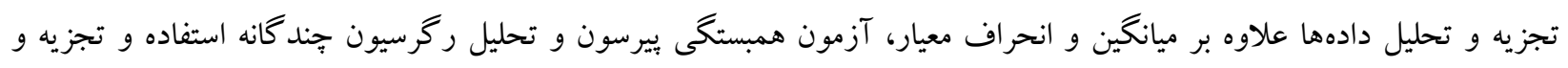

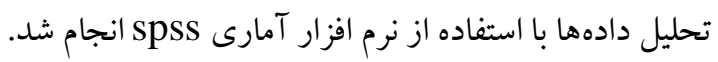

يافتها: بين نمره كلى تابآورى با آسيب:ذيرى روانى رابطه معنى دارى وجود دارد. در بين خرده مقياسها هم به ترتيب؛ افسردگى

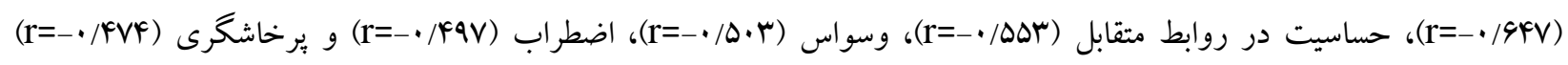

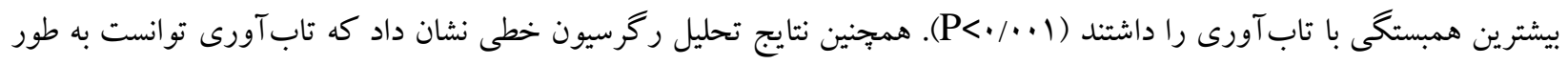

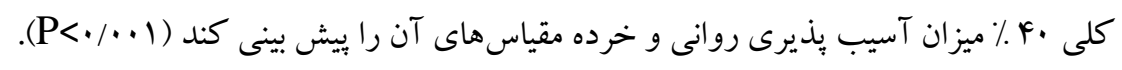

نتيجه كيرى: مىتوان نتيجه گُرفت كه افزايش تابآورى مىتواند به كاهش خرده مقياسهاى آسيبيذيرى روانى افراد منجر شود.

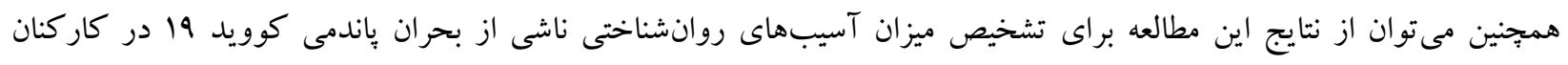

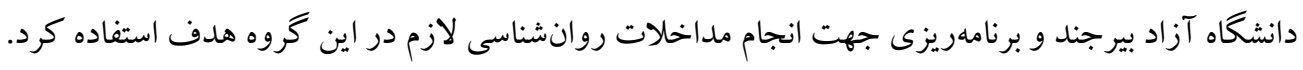
كليدوازهها: كوويد-91، آسيبذيذيرى روانى، تابآورى 


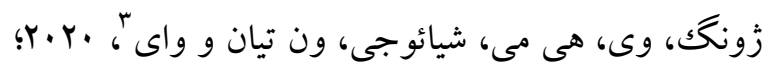

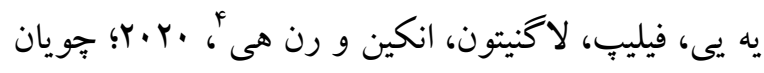

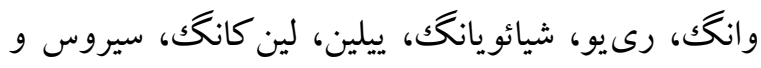
رو

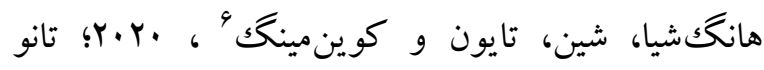

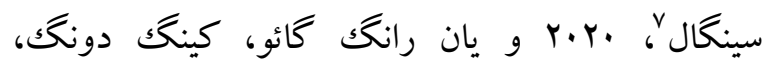

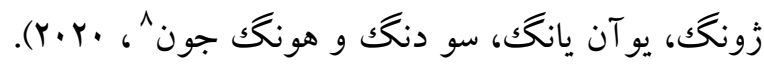
بيماران آلوده ممكن است به بيمارىهاى تنفسى شديد و

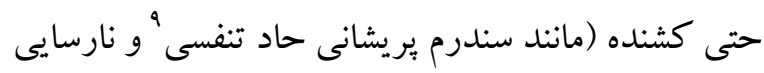

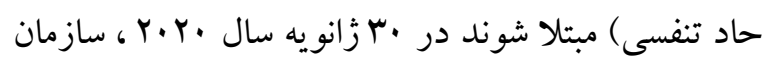
بهداشت جهانى شيوع كوويد 19 را به عنوان يكك بيمارى اضطرارى جهانى اعلام كرد (سازمان بهداشت جهانى "'،

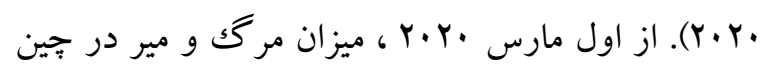

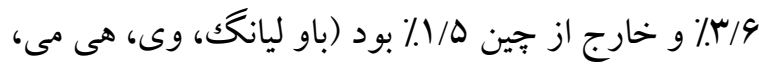

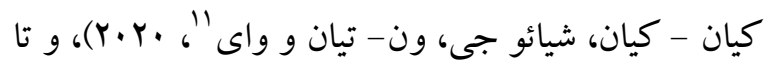
كنون بيش از · F كشور موارد بيمارى كووبد 19 را

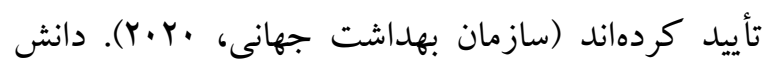
محدود در مورد كوويد 19 و اخبار غافلكيرانه ممكن است موجب اضطراب و ترس در بين مردم شود. عموم مردم در سطح وسيع نيز ممكن است تحت اقدامات

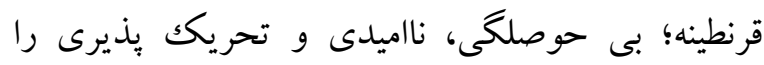
تجربه كنند. انتقال سريع كوويد 19 احتمال يريشانى ترئي روانى و عوارض روانى را در جمعيتهاى مختلف

33- Bao-Liang Zhong, Wei, Hai-Mei, Qian-Qian, Xiao-Ge, WenTian, Yi

4- Ye Yi, Philip, Lagniton, Enqin, Ren-He

5 - Cuiyan Wang, Riyu, Xiaoyang, Yilin, Linkang, Cyrus, Roger

${ }^{6}$ - Hao Xu, Liang, Jiaxin, Jiakuan, Hongxia, Xin, Taiwen, Qianming

7- Tanu Singhal

8. Yan-Rong Guo, Qing-Dong, Zhong, Yuan-Yang, Shou-Deng, Hong-Jun

9 - Acute Respiratory Distress Syndrome (ARDS)

${ }^{10}$ - WHO

${ }^{11}$ - Bao-Liang, Wei, Hai-Mei, Qian-Qian, Xiao-Ge, Wen-Tian \& $\mathrm{Yi}$
مقله رويدادهاى زيادى در زندگى هستند كه مىتواند بر

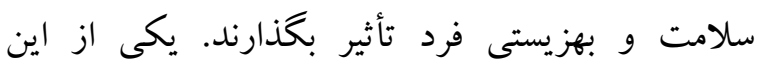

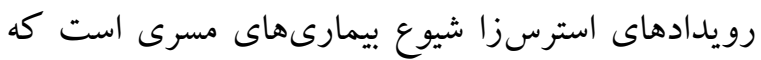

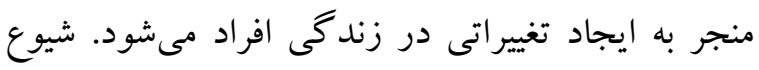
بيمارىهاى مسرى مى تواند به بيامدهايى با مقياس زياد

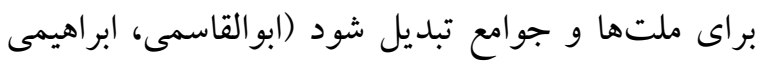
اردى، نريمانى و اسدى، آهجا). در حقيقت بيمارىهاى مسرى همواره تهديدى براى سلامتى و توليد مثل انسانها بودهاند (مرادى مطلق، نائينان، فتى، غلامى فشاركى و

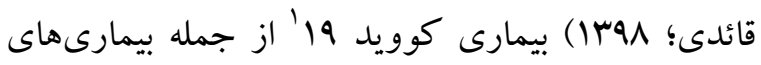
مسرى است كه در حال حاضر جامعه را دجار خالش و تنش كرده است. بيمارى كوويد 19 در اواخر زانويه سال r.r.r. جهان مورد توجه قرار كرفته است. بيمارى كوويد 19

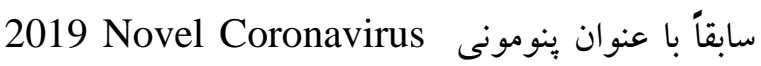
شناخته مى شد كه در اوايل دسامبر سال (2019-nCoV)

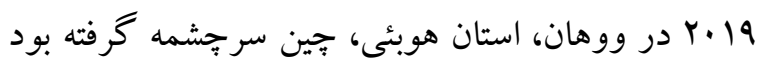

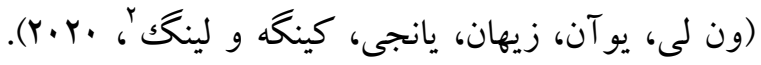

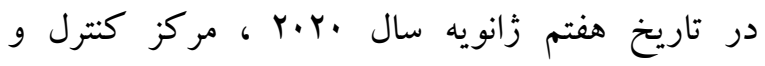

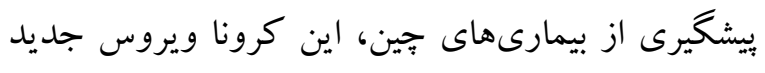
را به نام سندرم حاد تنفسى شناسايى و از بيمارى سارس جدا كرد كه مىتواند از طريق تماس نزديكك بين افراد

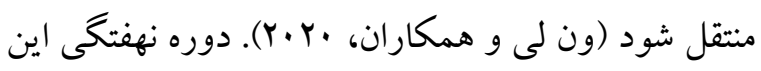
بيمارى از ب تأ أl روز است و شايعترين علائم آن شامل تب، خستخى، سرفه خشك، درد عضلات، سر گيجه، سردرد، كلودرد، آبريزش بينى، درد قفسه سينه، اسهال، حالت تهوع، استفراغ و تنخى نفس است (بائو ليانك إنك

\footnotetext{
1. COVID-19

${ }^{2}$ - Wen li, Yuan, Zi-Han, Yan-Jie, Qinge, Ling
} 
حوادث دلخراش و به عنوان خط سيرى از سلامت عملكرد در طول زمان تعريف شده است. بر اساس اين ديدكاه، تاب آورى فردى به توانيى فرد در استمرار عملكرد مناسب، در حين و بعد از بحران، يا حوادث دلخراش در همه سطوح رفتارى و فائق شدن موفقيت

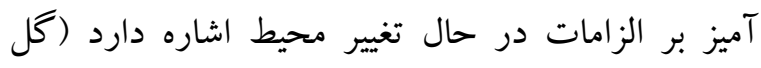

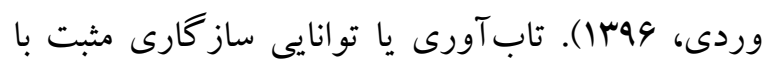

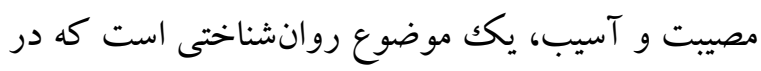

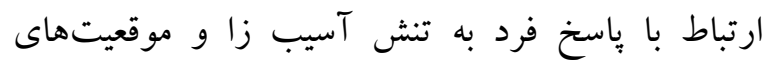

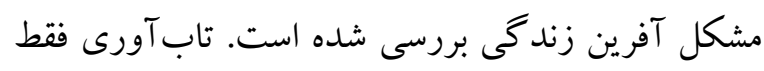

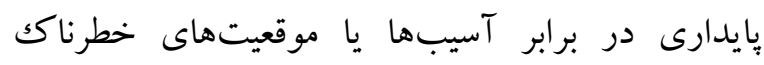
نيست، بلكه شركت فعال و سازنده در محيط ييرامون

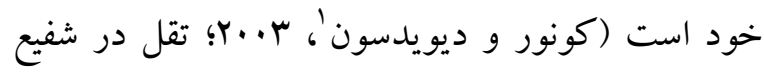
زاده، (14r). كاميفر (1999) در يزوهشى به اين نتيجه

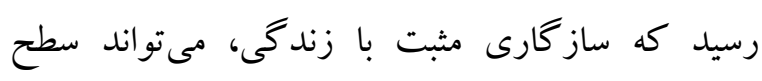
بالاترى از تاب آورى را سبب شود (به نقل از ابوالقاسمى،

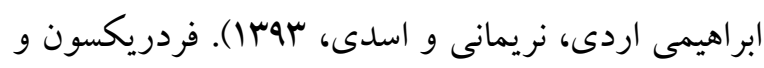
همكاران (r..r) در ئزوهشى دريافتند كه تفاوتهاى

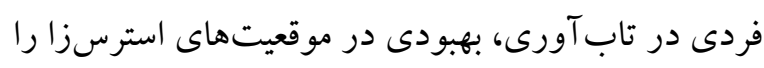
ييشبينى مى كند و افراد داراى تاب آورى بالا، بهبودى لئردي روانشناختى و هيجانى سريعترى از استرس به دست

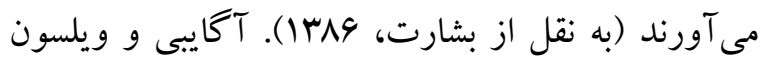

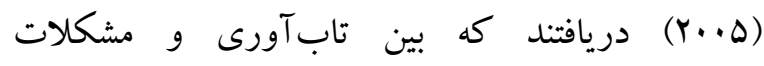
روانشناختى رابطه منفى معنادار وجود دارد (به نقل از

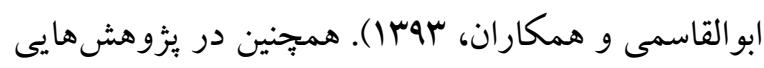
بين تابآورى و سلامت روانشناختى رابطه مثبت دانيت

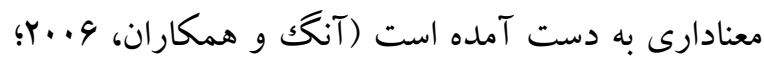

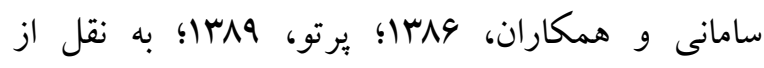

افزايش مىدهد، نه فقط به قرنطينه مداوم و به تصوير كشيدن اخبار منفى گسترده، بلكه به دليل افزايش تعداد موارد تأييد شده و مشكو كك و نيز مركى روزانه در جين و جهان كه خود نشان دهنده يكك رويداد تنش زاست. (ون لى و همكاران، ·.r.r.

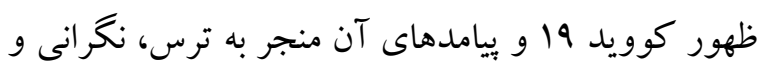
اضطراب در بين افراد در سراسر جهان شده است. اين بيمارى همجينين طيف گسترداى از مشكلات روانى مانند

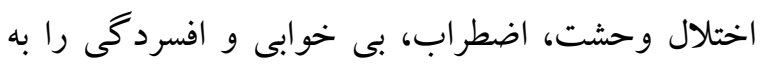
وجود آورده است (ون لى و همكاران، ·r.r.Y). به اعتقاد

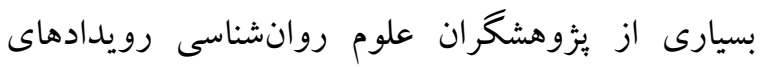
تنشزا در بروز اختلالات روانتنى نقش مؤثرى دارند. استرس هيجانى شديد مىتواند آسيب بذيرى فرد را در برابر بيمار شدن افزايش دهد و بهبودى از بيمارى را كند سازد (هالجين و ويتبورن، fأ.ب؛ ترجمه سيدمحمدى، هوجا). به عنوان مثال هولمز و راهه دريافتند كه

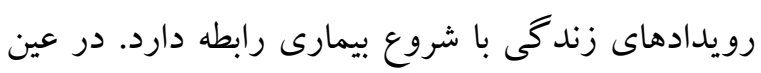
حال بررسىهاى روانشناسان بعدى نشان داد كه بين رويدادهاى تنشزا و اختلالات روانشناختى، عوامل تعديل كننده اى وجود دارد كه موجب مى تئود اين

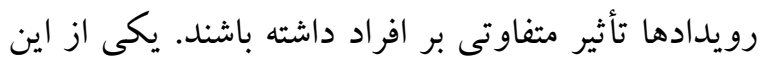

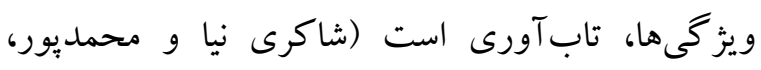

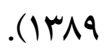

تاب آورى به معناى آماده شدن و برنامهريزى براى تحمل كردن، بازيابى يا ساز كارى موفقتر با حوادث ناخوشايند

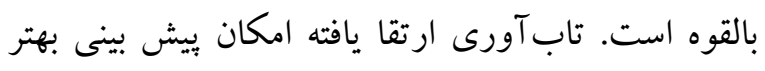
بلايا و برنامهريزى بهتر را به منظور كاهش لطمات اين بلايا فراهم مى كند. تاب آورى به وسيله بونابو به عنوان

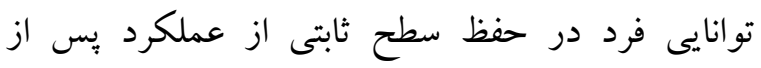

\footnotetext{
${ }^{1}$ - Connor \& Davidson
} 
انحراف معيار و آزمون همبستكى ويرسون و در سطح

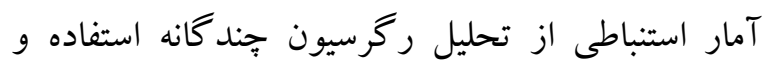

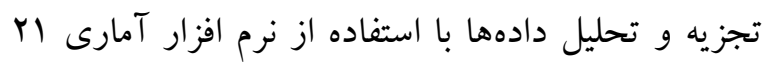
spss

\section{ابزار} ابزار مورد استفاده در اين پُخوهش شامل يُرسنامههاى زير مىباشد: يرسشنامه تابآورى كونور- ديويدسون'؛ اين ابزار توسط كونور و ديويدسون (r.... ساخته شد و داراى ها سؤ ال است كه سازه تابآورى را در اندازههاى ه درجه اى ليكرت ا تا ه مىسنجد. حداقل نمره در اين مقياس ها و و حداكثر نمره هrا است. محمدى (FAr) آن را براى استفاده در ايران هنجاريابى كرده است. براى تعيين روايى روش تحليلى جند عاملى مورد استفاده قرار گرفت. يايايى اين آزمون به كمكك ضريب آلفاى كرونباخ برابر با AV/ • به دست آمده است. كونور و ديويدسون ضريب آلفاى

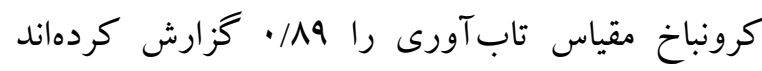

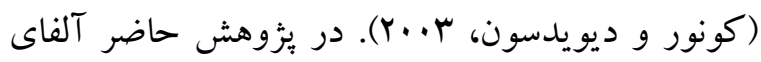

$$
\text { كرونباخ 9V/ • به دست آمد. }
$$

يرسشنامه نشانتان روانى "(scl-90): اين برسشنامه توسط دراكو تيس و همكارانش در سال سلوا1 معرفى شد و فرم نهايى آن در سال 9 ا تهيه گرديد. ابزار توسط رضايور 9. به فارسى ترجمه و استاندارد سازى شده است. شامل سؤال است كه اختلالات روانى رادر اندازههاى ليكرت ا تا ها مىسنجد (رئيسون، ميرى، دستجردى و شفيعزاده، MM IrM را گزارش كردهاند. ضرايب همبستكى بين V/ • تا ه/ • به اله

1. Connor\& Davidson Resilience Questionnaire

${ }^{2}$ - Symptom checklist - 90 revised

3- Sereda \& Dembitskyi
ابوالقاسمى و همكاران، سوبا). ابو القاسمى و همكاران (سوس () هم در بزوهشى دريافتند كه تاب آورى با آسيب بذيرى روانى مبتلايان به آسم رابطه معنادارى دارد. آرامش و سلامت روانى افراد مى تواند نقش به سزايى در

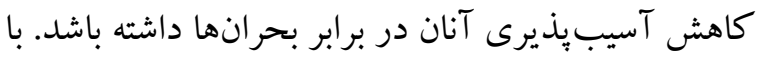
توجه به اينكه كشور و جهان درگير بحران شيوع ويروس كرونا است؛ لازم است كه اقداماتى براى بيدا كردن عوامل روانشناختى كه مىتواند با آسيب يذيرى روانى افراد مرتبط باشند انجام داد. با توجه به يزوهشهاى كذشته، تاب آورى مىتواند از جمله اين عوامل باشد. در نتيجه با توجه به شرايط كنونى (شيوع گسترده بيمارى)، و خطر بالاى ابتلا در مشاغل ادارى، اين بثرهش با هدف تعيين ارتباط بين تابآورى در برابر بحران كرونا با بان آسيب يذيرى روانى كاركنان دانشگاه آزاد اسلامى

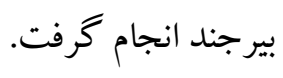

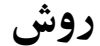

يثزوهش حاضر توصيفى از نوع همبستكى مىباشد. جامعه آمارى يثزوهش شامل تمامى كاركنان دانشگاه آزاد

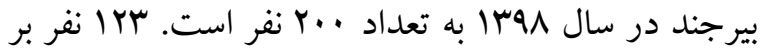
اساس جدول موركان به صورت تصادفى ساده به عنوان حجم نمونه انتخاب شدند. معيارهاى ورود به مطالعه شامل سن ·r r تا •9 سال و از كارمندان دانشگاه آزاد بيرجند(اعم از قراردادى، بيمانى، رسمى) باشد. معيار خروج از مطالعه شامل اينكه طى شش ماه كذشته واقعه تأسفبار مانند سوگك عزيزان، تصادف و يا ابتلا به بيمارى خطرناكك را نداشته باشد. برسشنامها به صورت آنلاين در اختيار نمونه مورد نظر قرار گرفت. براى تجزيه و تحليل دادهها در سطح آمار توصيفى، از ميانگين، 
ميانگين و انحراف معيار سن گروه نمونه كه سبا نفر از كاركنان دانشكاه آزاد بيرجند بودند

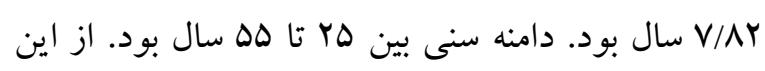

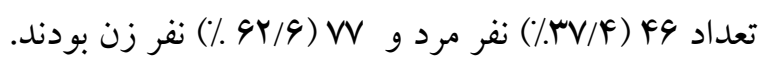

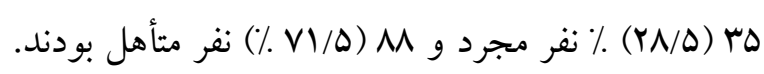

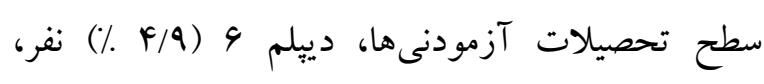
كاردانى ه (

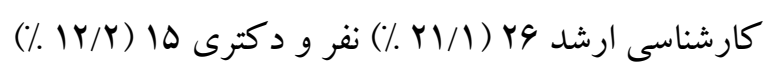

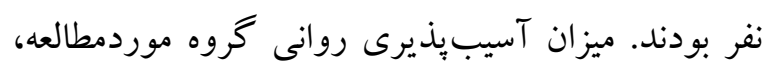

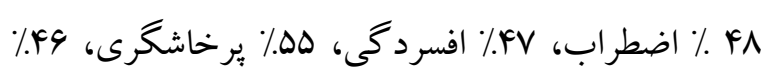

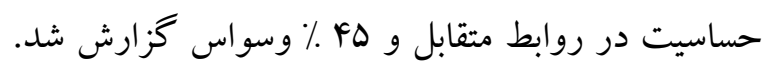

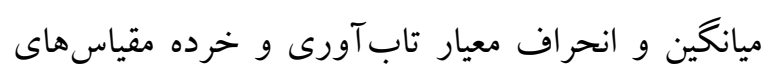

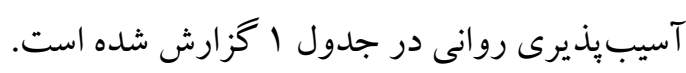

دست آمده است . در ايران هم رئيسون و همكاران

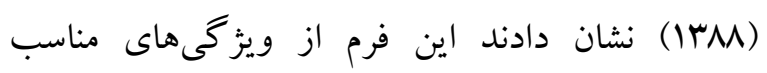
روانسنجى برخوردار است؛ به طورى كه اعتبار داخلى دانى

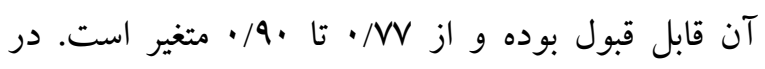
يُروهش حاضر نسخه YA سؤالى برسشنامه شامل خرده

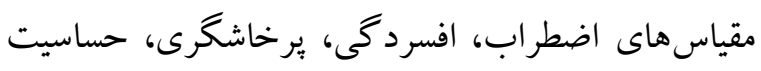
در روابط متقابل و وسواس مورد تجزيه و تحليل قرار

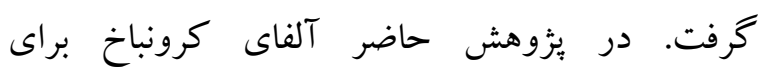

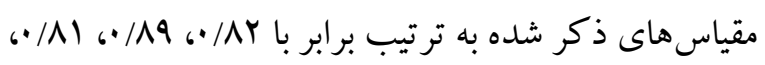

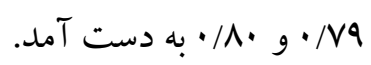

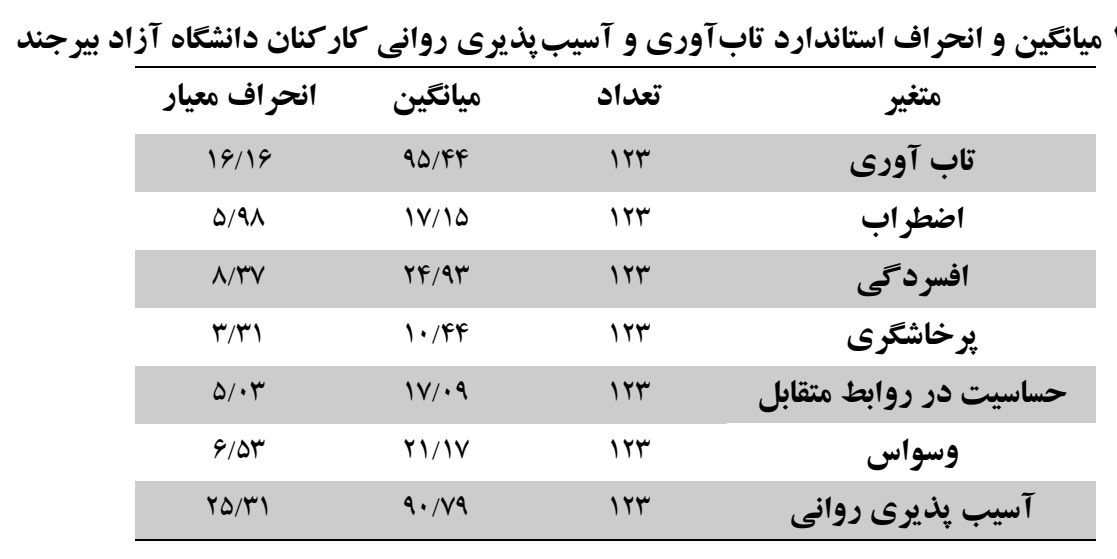

يّشبينى آسيبذيذيرى روانى، از ماتريس همبستخى و همانطور كه در جدول ا مشاهده مىشود ميانكين و

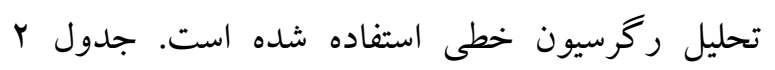

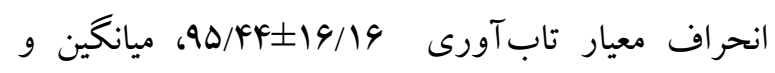
ماتريس همبستخى بين تاب آورى و خرده مقياسهاى آسيب بذيرى روانى را نشان مىدهد.

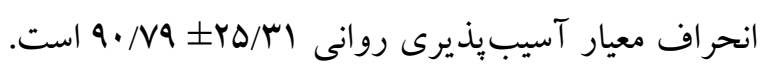

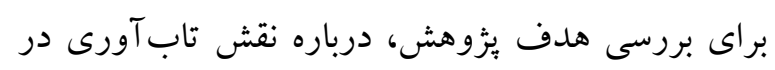

\section{جدول r ماتريس همبستكى نمرات تابآورى با آسيب يذيرى روانى در آزمودنىها}

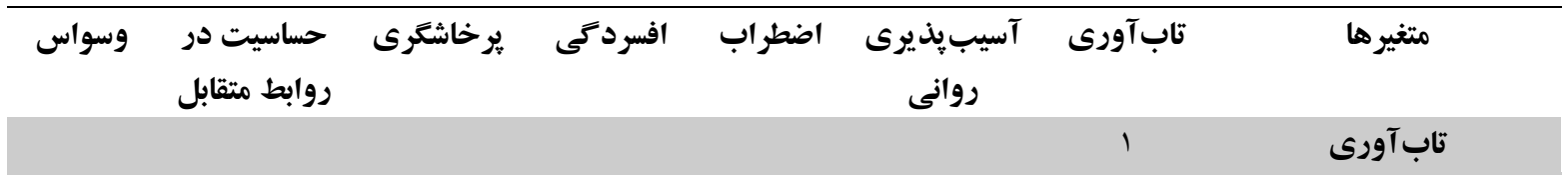




\begin{tabular}{|c|c|c|c|c|c|c|c|}
\hline & & & & & 1 & $-\cdot / 9 \mu \mathcal{F}^{* * * * *}$ & آسيب يذيرى روانى \\
\hline & & & & 1 & $\cdot / \Lambda 9 F^{* * *}$ & $-\cdot / \& q V^{* * * *}$ & اضطراب \\
\hline & & & 1 & 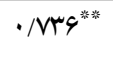 & . & $-\cdot / 9 \& V^{* * * * *}$ & افسردگى \\
\hline & & 1 & $\cdot / 90 \Lambda^{* * * * *}$ & $\cdot / \Delta r r^{* * * * *}$ & $\cdot / V \cdot \cdot^{* * *}$ & $-\cdot / F V \mathcal{F}^{* * * * *}$ & يرخاشكرى \\
\hline & 1 & $\cdot / \Delta Q r^{* * * * *}$ & $\cdot / V \Delta \Delta \Delta^{* * * * * *}$ & $\cdot 194 \cdot{ }^{* * * * * \pi}$ & $\cdot / \wedge \Delta \Delta^{* * * *}$ & $-\cdot / \Delta \Delta r^{* * * * *}$ & حساسيت در روابط متقابل \\
\hline 1 & $\cdot 199 V^{* * *}$ & $\cdot /$ FYA & $\cdot / V F Q^{\text {*****⿲二丨匕 }}$ & 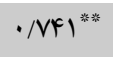 & $\cdot / A V F^{* * *}$ & $-\cdot / \Delta \cdot r^{* * * * *}$ & وسواس \\
\hline
\end{tabular}

${ }^{* *} \mathrm{P}<\cdot / \cdot \cdot 1$

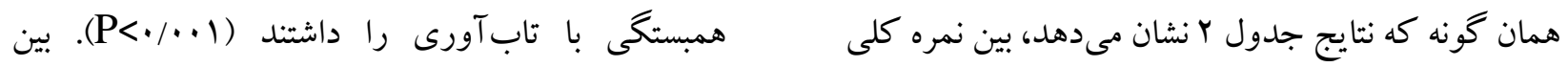

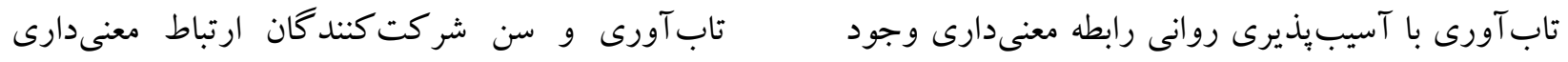

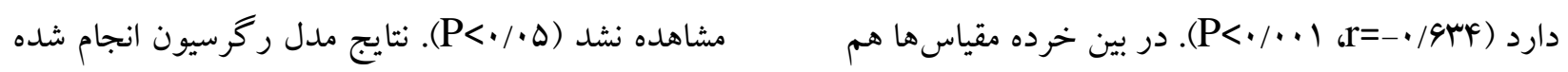
به ترتيب؛ افسردگى (r=-•/AFV)، حساسيت در روابط براى آزمون فرضيهى يزوهش در جدول r قابل مشاهده

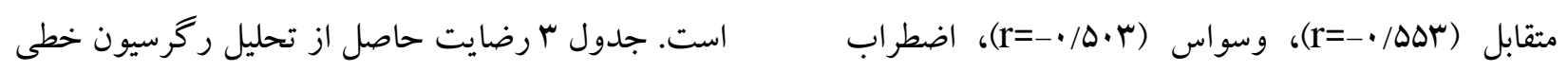

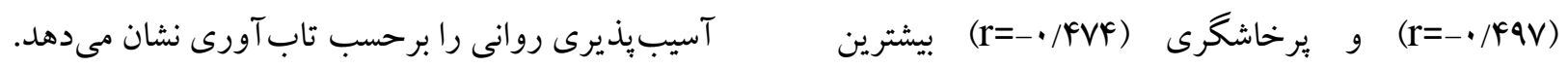

جدول نتايج تحليل ركرسيون خطى تابآورى بر خرده مقياسهاى آسيبذيرى روانى مورد مطالعه

\begin{tabular}{|c|c|c|c|c|c|}
\hline معنى سطارى & ضريب روكرسيونى استاندارد شده & B & ضريب & ضريب & متغير ملاكك \\
\hline$\cdot \cdots$ & $-\cdot / 94 \mathrm{~K}$ & $-/ 990$ & $\cdot / F \cdot r$ & $-\cdot 194 \mathrm{~F}$ & آسيبِيذيرى روانى \\
\hline$\cdot \cdots$ & $-\cdot / 49 V$ & $-\cdot / \wedge \uparrow$ & . IYFV & $-\cdot / 4 q V$ & اضطراب \\
\hline$\cdot \cdots$ & $-.194 \mathrm{~V}$ & 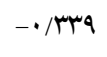 & $\cdot / 411$ & $-\cdot 19 F V$ & افسردگى \\
\hline$\cdot \cdots$ & $-\cdot / F V F$ & -1.91 & . /YYF & $-\cdot / F V F$ & يرخاشكرى \\
\hline$\cdot \cdots$ & $-\cdot / \Delta \Delta r$ & $-\cdot / I V r$ & $\cdot / \mu \cdot \Delta$ & $-\cdot / \Delta \Delta r$ & حساسيت در روابط متقابل \\
\hline.$\cdots$ & $-\cdot / 0 \cdot r$ & $-\cdot / r \cdot r$ & - rar & $-\cdot / 0 \cdot r$ & وسواس \\
\hline
\end{tabular}

نتايج تحليل رگرسيون خطى جدول r نشان داد كه وسواس، اضطراب، يرخاشگرى و حساسيت در روابط

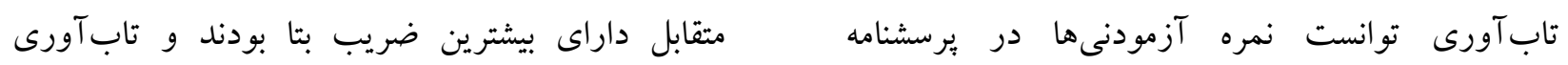
آسيب يذيرى روانى و خرده مقياسهاى آن را بيشينى توانست بخش قابل ملاحظهاى از واريانس اين خرده

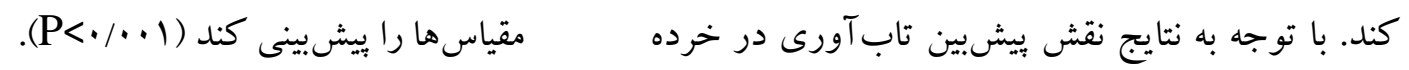

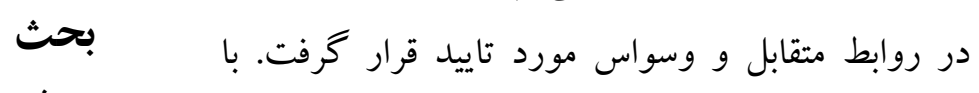

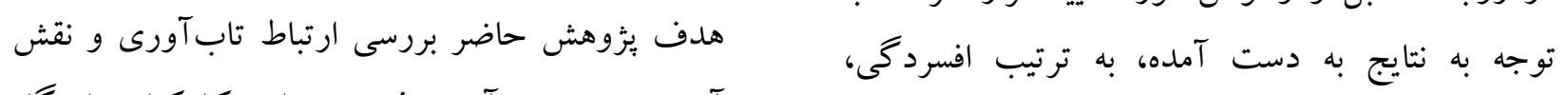

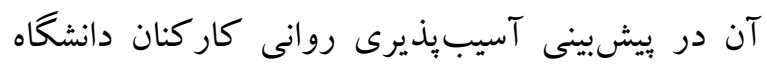


از ديخر نتايج يزوهش حاضر مىتوان به نقش بيشبينى كندكى تابآورى در خرده مقياسهاى آسيب بذيرى روانى است. اين نتايج با بثروهش آلبو كردى، نيكوسير

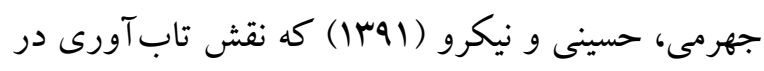
ييشبينى آسيب يذيرى روانى نوجوانان زندانى شيراز را مورد بررسى قرار دادهاند همسو است. همجنين نتايج حاضر با بزوهشى ابو القاسمى و همكاران (سوسا) با عنوان بررسى نقش سبكهاى دفاعى و تاب آورى در ييشبينى آسيب بذيرى روانى مبتلايان به آسم همسو است. اين

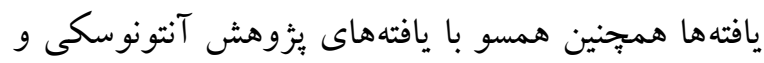
لازاروس است كه كاهش ميزان تابآورى در برابر رويدادهاى زندكى را در فرد، با نوعى احساس فشار

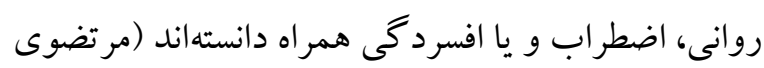

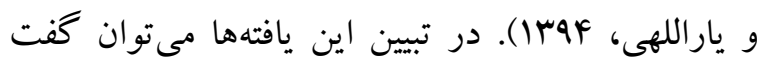

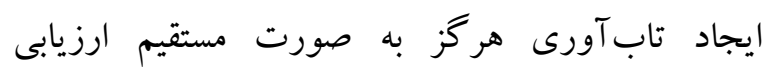
نمىشود بلكه بيشتر با وجود هر دو عامل احتمال خطر و بروز كفايت نتيجه مىدهد (به نقل از ابوالقاسمى و و بهو

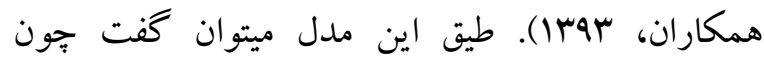
كار كنان دانشگاه احتمال خطر بيمارى را بالا و عامل بروز كفايت را يايين ارزيابى مى كنند، سطح تابآورى آنها دستخوش تغييرات منفى مىشود. همجنين با توجه به نظريههاى تاب آورى كه آن را يك فرايند ساز گارى موفقيت آميز با شرايط تهديد كننده مىداند (كارمزى و

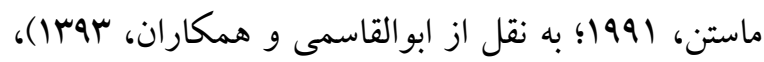
افرادى كه از سطوح تابآورى بايينى برخوردار باشند؛ در مقابل رويدادهاى استرس زا مقاومت كمترى دارند و لـ در نتيجه بيشتر مستعد آسيب روانى مىباشند (آنگك و همكاران، 9.+r؛ به نقل از ابوالقاسمى و همكاران،

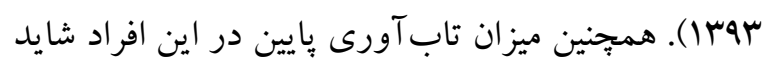

آزاد بيرجند بود. نتايج يُزوهش نشان داد كه ميزان

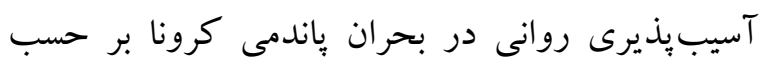

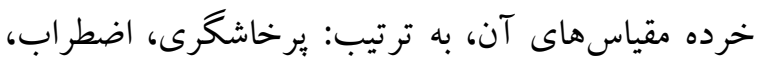

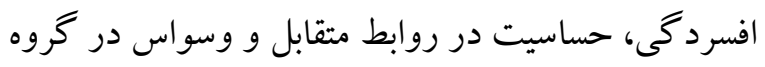

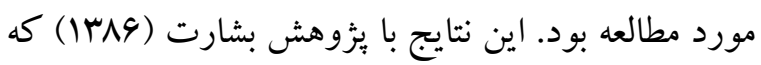
به بررسى رابطهى تاب آورى با شاخصهاى آسيب بذيرى

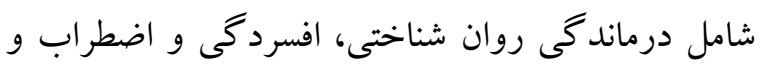
سلامت روانى يرداخته است همسو است. همجنين اين يافتها با نتايج يثزوهش ابو القاسمى و همكاران (سوبا)

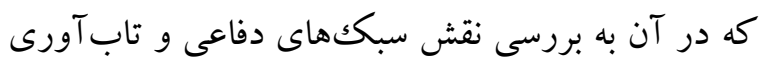
در يِيشبينى آسيب يذيرى روانى مبتلايان به آسم برداخته

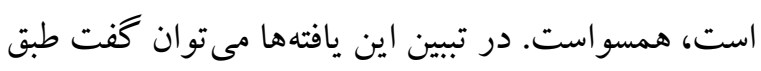

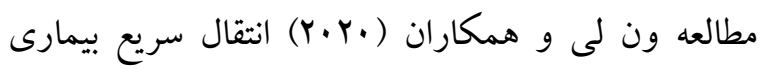
كوويد 191، نداشتن اطلاعات كافى در مورد آن، اخبار غافلكيرانه و اقدامات قرنطينه كه در آن تعداد زيادى از مردم در انزوا قرار گرفتند، باعث بروز طيف گستردهاى از مشكلات روانى مانند اضطراب، افسردگى، بى خوابى و اختلال وحشت شده است. همجنين شى يان رن و يه لى' (Y.Y. (Y. در مطالعه خود بيان داشتند " از نظر روانشناسى، افر اد در مواجهه با تغييرات محيط زندگى احساس نامنى، نآرامى و اضطراب مى كنند. بخصوص وقتى كه علت اييدمى مشخص نباشد، نگرشهاى غلط و شايعات اغلب شكوفا مىشوند. به كزارش سازمان جهانى بهداشت، افسردگى و اضطراب به عنوان دومين و برهزينهترين بيمارى بشر، به ويزه در كشورهاى در حال توسعه شناخته

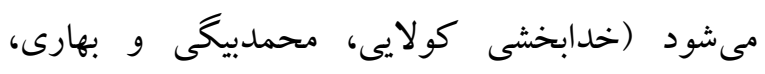
. (1)

\footnotetext{
1. Shi-Yan Ren \& Ye lee
} 
از يافتهاى فوق مىتوان جنين استنباط كرد كه افزايش

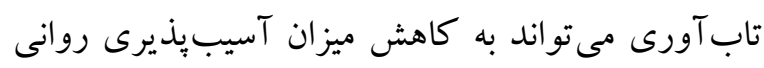
افراد منجر شود؛ لذا بيشنهاد مىشود در اين شرايط بحرانى، آموزشهاى تابآورى مورد توجه محققان و روانشناسان قرار گيرد. همجنان كه وايند، رايكبونئر، اندرسون و ريبر' (Y.Y.Y) نيز در مطالعه خود نتيجه كرفتند يكى از راهكارهاى مراقبت از سلامت روان در بحران ياندمى كرونا، برگزارى ويدئو كنفر انسهاى روانشناسى و مداخلات اينترنتى مىباشد. در يكك مطالعه مرورى برى سيستماتيك نيز نتايج نشان دادند ويدئو كنفرانسهاى روانشناسى تأثير بسزايى در كاهش اضطراب و اختلالات روانى داشتند (برى هيل، كالمر و ويليامز ب، 19. (Y).

\section{نتيجه كيرى}

نتايج اين مطالعه حاكى از وجود رابطه معنىدار و نقش ييشبينى كنندگى تابآورى در آسيب يذيرى روانى بود و مى توان نتيجه گرفت كه افزايش تاب آورى به كاهش ليش خرده مقياسهاى آسيب يذيرى روانى افراد منجر مىشود. در بين خرده مقياسهاى آسيب يذيرى روانى هم به ترتيب افسردگى، حساسيت در روابط متقابل، وسواس، اضطراب و يرخاشخرى بيشترين همبستگى را با تاب آورى داشتند. ماند ساير يزوهشها اين بزوهش نيز خالى از محدوديت

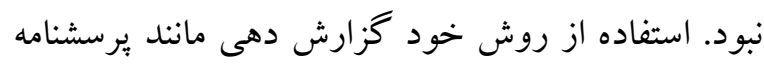
ممكن است با سو گيرى همراه باشد و اطلاعات دقيقى ارائه ندهد؛ بنابراين بهتر است در يُزوهشهاى آتى از روشهاى تركيبى جهت گردآورى دادهها استفاده شود. علاوه بر اين نتايج حاصل از اين بزوهش به دست آمده از

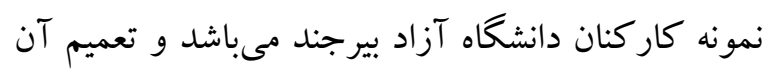

نشأت گرفته از اخبار و توصيه هاى مسئولان مبنى بر ماندن در خانه براى ييشخيرى از ابتلا به بيمارى كه اين خود از يرورش مؤلفهاى تابآورى در اين افراد جلوگيرى كرده و باعث مى شود اين افراد سطح تاب آورى بايينى را تجربه كنند. تابآورى با توانايى بالاى خودگردانى همراه مىشود كه شامل تعديل كردن سطح خود كنترلى شخص در سطوح بالا يا بايين است. تاب آورى افراد را از

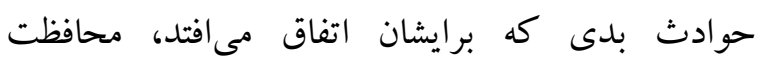

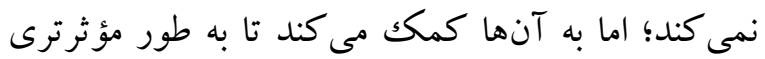
با استرس مقابله كنند (حسينى، زراعتكار، داورنيا و شاه-

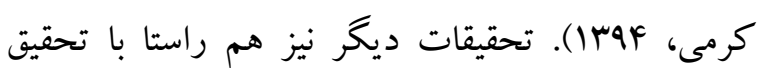
حاضر نشان داده است افرادى كه تابآورى بيشترى دارند در مقابله با مشكلات مقاومتر هستند و كمتر تحت تأثير مشكلات قرار مى گيرند و جنين جيزى باعث مىشود كه بِتى و بلندىهاى زندكى تأثير كمترى روى آنها بحذارد. تاب آورى به عنوان مقاومت موفقيت بـ آميز فرد در برابر موقعيتهاى تهديد آميز و جالش برانكيز عمل مى كند و افراد تاب آور افرادى هستند كه علىرغم مواجهه با استرسهاى مزمن و تنيد ملىها، از آثار نامطلوب آنها مى كاهند و سلامت روانى خود را حفظ مى كنند. افرادى كه داراى تاب آورى هستند، جاره ساز و انعطاف يذير بوده، مطابق تغييرات محيطى خود را وفق

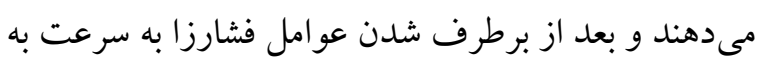
حالت بهبود باز مى گردند. افرادى كه در سطح بيايين

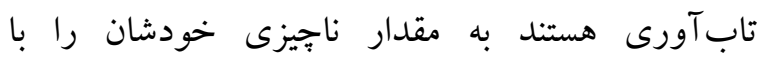
موقعيتهاى جديد وفق مى دهند، اينها به كندى از موقعيتهاى فشارزا به حالت عادى و طبيعى بهبود

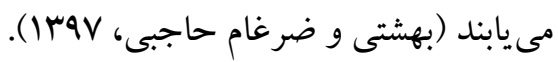

1. Wind, Rijkeboer, Andersson \& Riper

2. Berry Hill, Culmer \& Williams 
Beheshti A, Zargham Hajibi M. (2018). The relationship between resilience and practice of religious beliefs with anxiety and depression in soldiers. Joumal of Military Medicine. 20 (3), 333-341. (In Persian)

Berryhill MB, Culmer N, Williams N, Halli Tiemey A, Betancourt A, Roberts H, King $M$. (2019).Videoconferencing psychotherapy and depression: A systematic review. Telemedicine and e-Health. 25, 435-446.

Besharat MA. (2007). Resilience, Vulnerability and Mental Health, Journal of Psychological Sciences. 24, 373-383. (In Persian)

Connor K, Davidson J. (2003). Development of a new resilience scale: The Connor-Davidson Resilience Scale. Depression and Anxiety. 18(2), 76-82. Doi: 10.1002/da.10113

Cuiyan W, Riyu P, Xiaoyang W, Yilin T, Linkang X, Cyrus SH, Roger CH. (2020). Immediate Psychological Responses and Associated Factors during the Initial Stage of the 2019 Coronavinus Disease (COVID-19) Epidemic among the General Population in China. Int. J. Environ. Res. Public Health. 17, 1729. doi:10.3390/ijerph17051729

Gol Verdi M. (2017). National Resilience: A Review of Research Literature. Joumal of Public Policy Strategic Studies 7 (25), 294-310. (In Persian)

Halgin R, Cross Whitburn S. (2014). Psychological Pathology: Clinical Perspectives on Psychological Disorders Based on DSM-5. $9^{\text {th }}$ ed. Translated by Yahya Seyed Mohammadi (2019). Tehran: Ravan Publications. (In Persian)

Hao X, Liang Zh, Jiaxin D, Jiakuan P, Hongxia D, Xin Z, Taiwen L, Qianming Ch. (2020). High expression of ACE2 receptor of $2019 \mathrm{nCoV}$ on the epithelial cells of oral mucosa. International Journal of Oral Science. 12:8. doi: https://doi.org/10.1038/s41368-020-0074 $\mathrm{X}$

Hosseini A, Zeratkar K, Davar Nia R, Shakarami M. (2016). Predicting vulnerability to stress based on social support, resilience, coping strategies, and personality traits in students. Quarterly

$$
\begin{aligned}
& \text { به كاركنان اركانهاى ديخر، نيازمند يزٔوهش در همان } \\
& \text { موقعيتها است. با توجه به نتايج به دست آمده از اين } \\
& \text { مطالعه، بيشنهاد مىشود براى تشخيص ميزان آسيبهاى } \\
& \text { روانشناختى ناشى از بيمارى كرونا در كار كنان دانشگاه } \\
& \text { آزاد بيرجند و برنامهريزى جهت انجام مداخلات } \\
& \text { روانشناسى لازم در اين كروه برنامهريزى مناسب } \\
& \text { صورت يذيرد. } \\
& \text { سياسگزارى } \\
& \text { نويسند كان مطالعه حاضر لازم مى دانداند از تمامى كار كنان } \\
& \text { دانشگاه آزاد بيرجند كه در تكميل يرسشنامهها همكارى } \\
& \text { لازم را به عمل آوردند تشكر كنند. اين بززوهش به تأييد }
\end{aligned}
$$

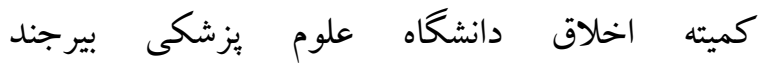

$$
\begin{aligned}
& \text { IR.BUMS.REC.1399.242 }
\end{aligned}
$$

\section{References}

Abolghasemi A, Ebrahimi Ardi Y, Narimani M, Asadi F. (2014). The role of defense and resilience styles in predicting the psychological vulnerability of people with asthma. Health Psychology. 3 (4), 80-91.(In Persian)

Albukordi S, Nikosir Jahromi M, Hosseini S, Nikro M. (2012). The relationship between resilience and mental disorders in young offenders in Shiraz Central Prison. Joumal of Kurdistan University of Medical Sciences. 17 (3), 43-50. (In Persian)

Bao-Liang Zh, Wei L, Hai-Mei L, Qian-Qian Zh, Xiao-Ge L, Wen Tian L, Yi L. (2020). Knowledge, attitudes, and practices towards COVID-19 among Chinese residents during the rapid rise period of the COVID-19 outbreak: a quick online cross-sectional survey. International Joumal of Biological Sciences. 16(10): 1745-1752. doi: 10.7150/ijbs.45221 
Journal of Cognitive and Behavioral Sciences Research. 6(2), 27-42. (In Persian)

Khodabakhshi Kolaei A, Mohammad Beigi M, Bahari F. (2016). The relationship between attachment to God and the resilience and mental health of parents of children with special needs. Joumal of Research in Religion and Health. 2(8), 7-14. (In Persian)

Mohammadi M. (2005). Investigating the Factors Affecting Resilience in People at Risk of Substance Abuse, PhD Thesis, University of Social Welfare and Rehabilitation Sciences, Tehran. (InPersian)

Moradi Motlagh M, Nainian M, Fati L, Gholami Fesharaki M, Qaedi GhH. (2019). Investigating the moderating role of perceived vulnerability to infectious disease in the relationship between multiple and fear of infection. Ibn Sina Clinical Medical Joumal. 26 (1), 34 43. Doi: 10.21859 / ajcm.26.1.34 (In Persian)

Mortazavi N, Yarullahi N. (2015). The meta-analysis of the relationship between resilience and mental health. Joumal of Mental Health Principles. 17 (3); 103-108. (In Persian)

Raeesun MR, Miri MR, Dastjerdi R, Sharifzadeh Gh. (2012). Investigation of the prevalence of mental disorders in Birjand city - 2009. Scientific Journal of Birjand University of Medical Sciences. 19 (1), 81- 87.(In Persian)

Shafizadeh R. (2012). Resilience relationship with five personality factors. Knowledge and Research in Applied Psychology. 13 (3) 96-102. (In Persian)

Shakemia I, Mohammadpour Shateri M. (2010). The relationship between job stress and resilience and bumout in female nurses. Joumal of Kermanshah University of Medical Sciences. 14 (2), 161-169. (In Persian)

Shi YR, Rong DG, Ye LCh. (2020). Fear can be more harmful than the severe acute respiratory syndrome coronavirus 2 in controlling the corona virus disease 2019 epidemic. World J Clin Cases 2020 February 26. 8(4), 652-657. DOI: 10.12998/wjcc.v8.i4.652
Tanu S. (2020). A Review of Coronavirus Disease2019 (COVID-19). The Indian Joumal of Pediatrics. 87(4), 281-286 doi: https://doi.org/10.1007/s12098-020-03263-6

Wen L, Yuan Y,Zi Han L, Yan Jie Zh, Qinge Zh, Ling Zh, \& et. (2020). Progression of Mental Health Services during the COVID-19 Outbreak in China. Intemational Joumal of Biological Sciences. 16(10), 1732-1738. doi: 10.7150/ijbs.45120

Wind TR, Rijkeboer M, Andersson G, Riper H. (2020). The COVID-19 pandemic: The 'black swan' for mental health care and a tuming point forehealth. Journal Pre-proof. 20, 1- 6. DOI: https://doi.org/10.1016/j.invent2020.100317

World Health Organization. (2020). Statement on the second meeting of the Intemational Health Regulations (2005) Emergency Committee regarding the outbreak of novel coronavirus (2019-nCoV). https://wwwwhoint/newsroom/detail/30-012020-statement-on-the-second-meeting-ofthe-intemation al-health-regulations-(2005)emergency-committee-regarding-theoutbreak-of-novel-coronavirus-(2019-ncov) (access Feb 17th, 2020).

Yan Rong G, Qing Dong C, Zhong Si H, Yuan Yang T, Shou Deng Ch, Hong Jun J, \& et (2020). The origin, transmission and clinical therapies on coronavirus disease 2019 (COVID-19) outbreak - an update on the Status. Military Medical Research. 7(11), doi: https://doi.org/10.1186/s40779-020-00240-0

Ye Y, Philip NP, Lagniton Sen Y, Enqin L, Ren He X. (2020). COVID-19: what has been leamed and to be leamed about the novel coronavirus disease. Intemational Joumal of Biological Sciences. 16(10), 1753-1766. doi: 10.7150/ijbs.45134 